\title{
Soboliphyme baturini (Nematoda: Soboliphymatidae) Recovered from Stomach of Asian Badger, Meles leucurus, in Geochang-gun, Gyeongsangnam-do, Korea
}

\author{
Woon-Mok Sohn*, Byoung-Kuk Na \\ Department of Parasitology and Tropical Medicine, and Institute of Health Sciences, Gyeongsang National University College of Medicine, \\ Jinju 52727, Korea
}

\begin{abstract}
We are going to describe the female soboliphymid nematodes, which were recovered from the stomach of a Asian badger, Meles leucurus (Mammalia: Mustelidae), in Geochang-gun, Gyeongsangnam-do, Korea. In February 1998, we found 2 peculiar nematodes with a cup-like organ in the anterior end from the stomach of badger. Recovered worms were fixed with $10 \%$ formalin, cleared in glycerin-alcohol solution and observed under a light microscope with a micrometer. They were 34.46 (33.43-35.50) mm long by $2.13 \mathrm{~mm}$ at maximum width. Cephalic sucker cup-like, 3.34 (3.13-3.55) $\mathrm{mm}$ wide, $2.40(2.25-2.55) \mathrm{mm}$ long, with the oral aperture and meridionally striated on the buccal capsule. Oral aperture $2.38 \mathrm{~mm}$ in diameter. Circumoral membrane $0.41(0.38-0.45) \mathrm{mm}$ wide. Esophagus muscular, 4.81 (4.50-5.00) $\mathrm{mm}$ long by $0.80(0.78-0.83) \mathrm{mm}$ at maximum width. Vulva situated at $3.13 \mathrm{~mm}$ ventro-anterior level from the esophago-intestinal junction. Vagina anteriad, $3.38 \mathrm{~mm}$ long, making a canal from the uterus to the vulva opening. Uterus single, large. Tail 0.35 (0.33-0.38) mm long. Intrauterine eggs long elliptical, 0.058-0.065 (0.062) mm long and 0.030-0.033 (0.031) mm wide. Based on the some morphological characters and host-specificity, our specimens are nearly identical with $S$. baturini. Therefore, the present report describes S. baturini for the first time in Korea.
\end{abstract}

Key words: Soboliphyme baturini, Badger, Meles leucurus, Republic of Korea

Nematode members in the genus Soboliphyme (Nematoda: Soboliphymatidae) are the gastro-intestinal parasites of carnivores and insectivores. About 9 species, i.e., Soboliphyme abei, S. ataahai, S. baturini, S. caucasica, S. huridiniformis, S. jamesoni, S. occidentalis, S. soricis, and S. urotrichi, have been reported in the literatures [1-7]. It has been known that soboliphymid nematodes have 2 hosts in their life cycle. Larvae develop in oligochaetes, earthworm, and adults dwell in the gastro-intestinal tract of insectivorous and carnivorous mammals by the eating of intermediate and/or paratenic hosts with larvae [2,3]. However, there are no reports on the soboliphymid nematodes in Korean fauna. We describe with 2 female soboliphymids recovered from the stomach of a Asian badger, Meles leucurus (Mammalia: Mustelidae), in Geochang-gun, Gyeongsangnam-do, Korea.

- Received 3 August 2019, revised 24 September 2019, accepted 25 September 2019. *Corresponding author (wmsohn@gnu.ac.kr) (c) 2019. Korean Society for Parasitology and Tropical Medicine This is an Open Access article distributed under the terms of the Creative Commons Attribution Non-Commercial License (http://creativecommons.org/licenses/by-nc/4.0) which permits unrestricted non-commercial use, distribution, and reproduction in any medium, provided the original work is properly cited.
In February 1998, we obtained a whole set of visceral organs and some muscles of a badger from a wholesale house of animals located in Geochang-gun, Gyeongsangnam-do, the Republic of Korea (Korea) to examine the infection of Trichinella larvae. We also examined helminthic infections from the badger and recovered 2 peculiar nematodes with a cup-like organ in the anterior end from the stomach. Recovered worms were fixed with 10\% formalin, cleared in glycerin-alcohol solution and observed under a light microscope with a micrometer.

They were female worms with a cup-like structure in the anterior and a pointed tail in the posterior ends. Their morphological characters were as follow (Fig. 1). Body 34.46 (33.43$35.50) \mathrm{mm}$ long and $2.13 \mathrm{~mm}$ at maximum width. Cephalic sucker cup-like, 3.34 (3.13-3.55) mm wide, 2.40 (2.25-2.55) $\mathrm{mm}$ long, with the oral aperture and meridionally striated on the buccal capsule. Oral aperture (opening) $2.375 \mathrm{~mm}$ in diameter. Circumoral membrane 0.413 (0.38-0.45) mm wide. Esophagus muscular, 4.81 (4.50-5.00) mm long and 0.80 (0.78-0.83) $\mathrm{mm}$ at maximum width. Vulva situated at 3.125 $\mathrm{mm}$ ventro-anterior level from the esophago-intestinal junc- 

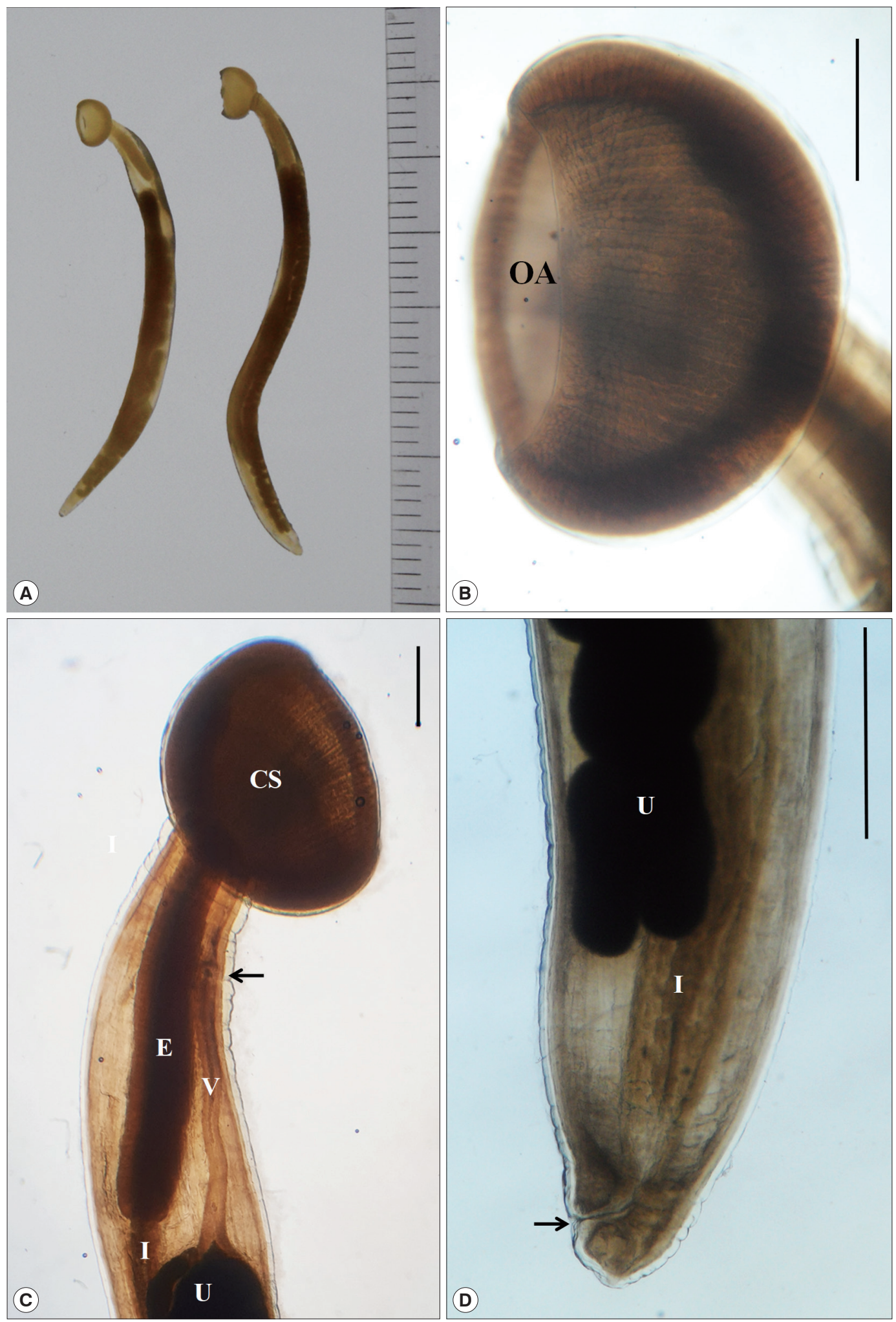

Fig. 1. (A) Two female worms of Soboliphyme baturini recovered in the stomach of badger, Meles leucurus, from Geochang-gun, Gyeongsangnam-do, Korea. (B) Magnified view of cephalic sucker with the oral aperture (OA) and meridionally striated on the buccal capsule. (C) Anterior portion with a characteristic cephalic sucker (CS), muscular esophagus (E), intestine (I), uterus (U), long vagina $(M)$ and vulva opening (arrow). (D) Posterior portion with the uterus (U), intestine (I) and anus (arrow). Scale bar=1 mm. 
Table 1. Comparative dimensions ${ }^{\text {a }}$ of Soboliphyme spp. with those of previous studies

\begin{tabular}{lcccc}
\hline Organs & $\begin{array}{c}\text { Present study } \\
\text { (Sohn et al., 2019) }\end{array}$ & $\begin{array}{c}\text { S. baturini } \\
\text { (Swartz, 1968) }\end{array}$ & $\begin{array}{c}\text { S. ataahai } \\
\text { (Ganzorig et al., 2003) }\end{array}$ & $\begin{array}{c}\text { S. occidentalis } \\
\text { (Ribas et al., 2004) }\end{array}$ \\
\hline Body (BL) & $33.43-35.50(34.46)$ & $17.5-24.1$ & $23.6-35.8(33.7)$ & $21.89-24.62(22.41)$ \\
Body (BW) & $(2.13)$ & $1.33-1.63$ & $1.12-1.70(1.40)$ & $0.78-0.97(0.95)$ \\
Ratio of BW:BL & $01: 16.2$ & $01: 14.0$ & $01: 24.1$ & $01: 23.8$ \\
Cephalic capsule (L) & $3.13-3.55(3.34)$ & $2.01-2.45$ & $1.51-1.97(1.66)$ & $1.38-1.60(1.51)$ \\
Cephalic capsule (W) & $2.25-2.55(2.40)$ & in diameter & $1.48-1.70(1.55)$ & $1.27-1.38(1.30)$ \\
Esophagus (L) & $4.50-5.00(4.81)$ & $3.04-4.02$ & $3.30-4.58(3.79)$ & $4.32-4.38(4.35)$ \\
Location ${ }^{b}$ of vulva & Anterior level & Anterior level & E-I junction level & Posterior level \\
Vagina (L) & 3.38 & - & $2.36-2.92(2.71)$ & $0.73-0.95(0.84)$ \\
Tail (L) & $0.33-0.38(0.35)$ & $0.14-0.32$ & $0.47-0.64(0.62)$ & $0.30-0.43(0.42)$ \\
Eggs (L) & $0.058-0.065(0.062)$ & $0.054-0.063$ & $0.080-0.115$ & $0.079-0.082$ \\
Eggs $(\mathrm{W})$ & $0.030-0.033(0.031)$ & $0.032-0.036$ & $0.042-0.069$ & $0.038-0.041$ \\
Host & Asian badger & American mink & Laxmann's shrew & Iberian mole \\
& Meles leucurus & Neovison vison & Sorex caecutiens & Talpa occidentalis \\
\hline
\end{tabular}

aOnly female worms: (L) length; $(W)$ : width; unit is $\mathrm{mm}$.

bocation from esophago-intestinal (E-I) junction.

tion. Vagina anteriad, $3.38 \mathrm{~mm}$ long, making a canal from the uterus to the vulva opening. Uterus single, large. Tail 0.35 (0.33$0.38) \mathrm{mm}$ long. Intrauterine eggs long elliptical, 0.058-0.065 (0.062) mm long and 0.030-0.033 (0.031) mm wide (Table 1).

Among 9 soboliphymid nematodes reported in the literatures, 8 species, i.e., S. abei, S. ataahai, S. caucasica, S. huridiniformis, S. jamesoni, S. occidentalis, S. soricis and S. urotrichi, are detected in insectivores, shrews and moles. Only 1 species, $S$. baturini, has been found in carnivorous mammals in adult stage like in this study [1-7]. Over 32 species of mammals have been listed as the hosts of this nematode species [8]. Adult worms of $S$. baturini are most commonly detected in sable and marten (Martes spp.), and less frequently found in ermine and weasel (Mustela spp.), wolverine (Gulo gulo), and mink (Neovison vison) [8]. Larval and/or juvenile worms are found in shrew (Sorex spp.), canids and felids, which acted as the paratenic and incidental hosts in the life cycle. In the aspect of hostspecificity, our specimen is closely related with $S$. baturini. Moreover, the European badger, Meles meles, has been listed as the definitive host of $S$. baturini [8-10].

Soboliphymids residing in insectivores are known to be host-specific and restrictive in distribution. Cross infections between soboliphymids of shrews and moles do not occur. Four Soboliphyme spp., S. abei, S. ataahai, S. jamesoni and S. sor$i c i s$, have been detected from shrews and 4 species, $S$. caucasica, S. hirudiniformis, S. occidentalis and S. urotrichi, have been found from moles. On the other hand, 4 species, i.e., S. caucasica, S. hirudiniformis, S. occidentalis and S. soricis, are distributed in Europe only, 3 species, S. abei, S. ataahai, and S. urotrichi, appear to be restricted to Asia, and only one species, S. jameso$n i$, occurs in North America [3-5,11-14]. Only one species that parasitizes in carnivores, $S$. baturini, is broadly distributed in Eurasia and North America [3,15].

Six of the 9 soboliphymid nematodes previously reported, i.e., S. ataahai, S. baturini, S. huridiniformis, S. occidentalis, S. soricis and S. urotrichi, have the notched cephalic sucker. Among these, only 2 species, $S$. baturini and S. huridiniformis, have the vulva opening at the ventro-anterior from the esophago-intestinal junction like in our specimens (Table 1). However, $S$. huridiniformis is found only in the insectivores, moles. The 2 specimens in this study are considerably larger than those of previous descriptions for $S$. baturini $[16,17]$, but similar with those of S. sahalinense Shimakura and Odajima, 1934 [18], which has been considered to be a synonym of $S$. baturini $[2,3]$. Some limited points, i.e., lack of male worms and insufficient number of female samples, exist in this study, but our specimens are closely identical with some morphologies of $S$. $b a$ turini.

Based on the some morphological characteristics and hostspecificity, the soboliphymid nematodes recovered from the stomach of badger were identified as $S$. baturini in this study. Accodingly, we report for the first time that the Asian badger, M. leucurus, serves as the definitive host for S. baturini, and this species of nematode is distributed in Korean peninsula. Further studies on the soboliphymid nematodes should be performed in insectivores as well as in carnivores to expand the nematode fauna in Korea. 


\section{CONFLICT OF INTEREST}

We declare that we have no conflict of interest related to this work.

\section{REFERENCES}

1. Read CP. Soboliphyme jamesoni n. sp., a curious nematode parasite of California shrews. J Parasitol 1952; 38: 203-206.

2. Yamaguti S. Systema Helminthum. Vol. 3: The Nematodes of Vertebrates. New York, USA. Interscience. 1961, pp 532-535.

3. Karmanova EM. Dioctophymidea of Animals and Man and Diseases Caused by Them. Fundamentals of Nematology, Vol. 20. New York, USA. Amerind Publishing Company Private. 1986, pp 383.

4. Machida M, Uchida A. Some helminth parasites of the Japanese shrew mole from the Izu Peninsula. Mem Nat Sci Mus (Tokyo) 1982; 15: 149-154.

5. Asakawa M, Kamiya H, Ohbayashi M. Studies on the parasite fauna of insectivora III. Two new nematodes, Soboliphyme abei $\mathrm{n}$. sp. (Soboliphymatidae) and Stefanskostrongylus yagii n. sp. (Angiostrongylidae) from Sorex spp in Japan. J Rakuno Gakuen Univ 1988; 13: 1-10.

6. Ganzorig S, Batsaikhan N, Oku Y, Kamiya M. A new nematode, Soboliphyme ataahai sp. n. (Nematoda: Soboliphymidae) from Laxmann's shrew, Sorex caecutiens Laxmann, 1788 in Mongolia. Parasitol Res 2003; 89: 44-48.

7. Ribas A, Casanova JC. Soboliphyme occidentalis sp. nov. (Nematoda, Soboliphymidae) from the Iberian mole Talpa occidentalis (Insectivora, Talpidae) in Spain. Parasitol Res 2004; 93: 482-485.

8. Koehler AVA, Hoberg EP, Dokuchaev NE, Cook JA. Geographic and host range of the nematode Soboliphyme baturini across Beringia. J Parasitol 2007; 93: 1070-1083.

9. Karpenko SV, Dokuchaev NE, Hoberg EP. Nearctic shrew, Sorex spp., as paratenic hosts of Soboliphyme baturini (Nematoda: Soboliphymatidae). Comp Parasitol 2007; 74: 81-87.

10. Dominich IF. The shrew, Sorex caecutiens, a reservoir host of the nematode Soboliphyme baturini. Parasitologiya 1982; 16: 497499.

11. Baylis HA, King LAL. A new nematode parasite of the common shrew. Ann Mag Nat Hist 1932; 9: 58-64.

12. Barus V, Tenora F, Wiger R. Further occurrence of some helminths in rodentia and insectivora from Fennoscadia. Folia Parasitol 1977; 24: 127-138.

13. Melnichenko ED, Panasenko NA. On the helminth fauna of certain insectivorous mammals of the Middle Dnieper area. Vest Zool 1979; 5: 79-81 (in Russian).

14. Meszaros F, Murai E, Matsaki I. Helminths of Sorex alpinus Schinz, 1837 (Trematoda, Cestoda, Nematoda, Acanthocephala) in the West-Carpathian Mountains (Slovakia). Parasitol Hung 1982; 14: 83-86.

15. Swartz LG. A new natural definitive host, and morphometry of Soboliphyme baturini Petrow, 1930 in interior Alaska. Can J Zool 1968; 46: 691-693.

16. Bezdek H. Studies on the nematode Soboliphyme baturini Petrow, 1930. Trans Am Microsc Soc 1942; 61: 398-403.

17. Schmidt GD, Kinsella JM. Contribution to the morphology of Soboliphyme baturini Petrow, 1930 (Dioctophymoidea: Nematoda). Trans Am Microsc Soc 1965; 84: 413-415.

18. Shimakura K, Odajima K. Soboliphyme sahalinense, n. sp., (Nematodes) from Martes zibellina sahalinensis Ognev. Trans Sapporo Nat Hist Soc 1934; 13: 341-350. 